\title{
European labs begin parallel processing computer project
}

\begin{abstract}
Munich. The European particle physics laboratory CERN and the European centre for mathematics in Toulouse, France, which analyses metereological data, are leading a three-year project in massively parallel processing as part of an ESPRIT programme to promote information technology in Europe.
\end{abstract}

Funds of ECU15 million (US\$21.8 million) will be used to provide hardware and develop software for a technology that competes with standard vector computers. Each laboratory, which is obliged to match the grant from the European Commission (EC) with money from its own budget, will be installing a scalable CS-2 parallel computing machine built by the British company Meiko. The computers will be used to develop software to analyse vast amounts of particle physics and meteorological data, which are currently analysed by Cray vector supercomputers.

Parallel processing is capable of higher overall performance compared to vector computers, particularly important for specialist scientific, high-input high-output data analysis such as that generated at CERN. "We are not a typical vector user", says Fabrizio Gagliari, project manager at CERN, "because our work is as much computer intensive as data intensive". Massively parallel computers have the added advantage, for all users, of being much cheaper to build and to run than vectors.

The EC hopes that the project, which began last month, will increase user confidence in the potential of the European massively parallel computers and will create a market for supporting companies. A recent report on high-performance computing in Europe, compiled by CERN director Carlo Rubbia for the EC, concludes that Europe can compete effectively with US companies, traditionally the leaders in the supercomputing field, provided that support is given to overcome the perennial problem of turning basic research results into competitive products. The EC hopes to build upon Europe's acknowledged strength in software development.

Japan, although further behind in the race, is forming collaborations to close the gap. Last month NEC signed an agreement with the Swiss scientific computing centre (CSCS) to develop applications for massively parallel computers in a new, NECfunded high performance computing software development centre on the CSCS site.

Meiko is part of a three-way consortium of suppliers that will benefit from the EC project; its partners are the British company Parsys and the French company Telmat.

Alison Abbott

\section{New, greener ethos bolsters bill to protect California desert}

Washington. A 17-year effort to protect some seven million acres of federally owned desert in California seems to be on the brink of success, the result of a new president and changing attitudes in Congress.

A campaign by environmental groups to shield the fragile Mojave and Sonoran deserts from the impact of mining, ranching, military and off-road use has long been opposed by the Reagan and Bush administrations and by the lobbying interests of the people who work and play in the desert. But Interior Secretary Bruce Babbitt has pledged that preserving California's desert will be the first land conservation goal of the Clinton administration. Babbitt's announcement came a month after California's two newly elected Democratic senators introduced a bill to preserve one-third of the federally owned desert land in their state, a measure that is expected to become law by this summer.

The Mojave and Sonoran deserts cover 40,000 square miles of remarkably diverse terrain. Sand dunes, dry lakes, extinct volcanoes and 90 mountain ranges dot the landscape, and there are 760 animal and 1,300 plant species.

The California Desert Protection Act would create a 1.5 million-acre Mojave National Monument in the East Mojave, which houses the world's largest Joshua tree groves as well as the greatest population of the threatened desert tortoise. It would transfer supervision of the areas from the Bureau of Land Management (BLM) to the National Parks Service and would bring to an end the existing cattle ranching, mining activity and off-road vehicle use. The bill would also add 1.3 million acres to Death Valley and 200,000 acres to Joshua Tree national monuments, transforming both into more tightly controlled national parks.

"We've all seen this initiative stymied far too long", Senator Dianne Feinstein said about her bill, cosponsored by Senator Barbara Boxer. "Now the important thing is to get the ball rolling and protect what's left of the desert."

The federal government owns about half of California's entire desert wilderness. Of that land, about 15 per cent is used by the military as training grounds for flight, bombing and land warfare exercises. On any given day, sonic booms rattle the land near Edwards Air Force Base, while soldiers practising tank battles at Fort Irwin leave dust clouds visible more than a hundred miles away.

The most controversial aspect of the proposed legislation would set aside an additional four million acres of desert as "federal wilderness areas", prohibiting roads and motor vehicles and limiting mining, military activity and livestock grazing. It is not surprising, therefore, that most people who earn their livelihood in the desert oppose the measure.

"It's going to kill us", says Dave Fisher, who for 29 years has operated two ranches totalling 270,000 acres in the western

\section{IMAGE UNAVAILABLE FOR COPYRIGHT REASONS}

Mojave; some 80 per cent would be reserved as wilderness under the legislation. The bill's effect on mining, the desert's biggest industry, would be even more dramatic. The ending of mining rights would lead to a loss of some 20,000 jobs and $\$ 2$ billion in revenue over the next seven years.

"If concessions aren't made for those who live in the desert, the results would be economically disastrous", says US Representative Jerry Lewis (Republican, California), who represents most of the rural Mojave.

Most of the federally owned land in the area is run by BLM, which has apportioned it for extensive commercial mining and ranching as well as for recreational use. Each year, mining levels mountain peaks and kills off plant and animal species that have adapted to the habitat over thousands of years. Equally threatening are the dozens of federally subsidized cattle ranches that have depleted underground water sources used by antelope and bighorn sheep. The BLM has also set aside 1.5 million acres of formerly pristine wilderness for unlimited shooting ranges and for use by jeeps, dune buggies and dirt bikes.

More recently, the BLM has leased large tracts of wilderness to be used as garbage dumps for cities in the Los Angeles area. And later this year, the agency plans to sell land near the Colorado River for the nation's largest unlined low-level radioactive waste dump.

Susan Greene 